\title{
Chapter
}

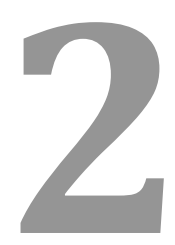

\section{EXPLORING BIODEGRADABLE POLYMER PRODUCTION FROM MARINE MICROBES}

Kulanthaisamy Mohan Rasu ${ }^{1}$ and Alagarsamy Arun ${ }^{* 2}$

${ }^{1}$ Department of Energy Science, Alagappa University, Karaikudi

${ }^{2}$ Department of Microbiology, Alagappa University, Karaikudi 


\section{Contents}

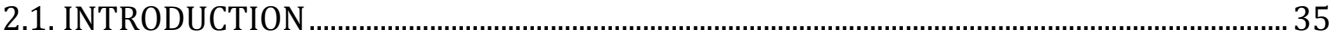

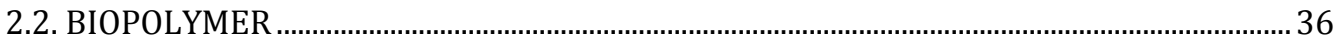

2.3. MARINE ENVIRONMENT POLLUTION DUE TO PLASTICS ……............................................. 37

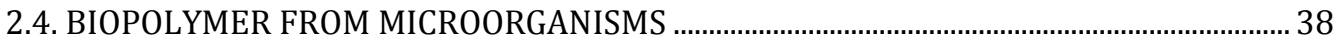

2.5. MARINE BACTERIA POTENTIAL

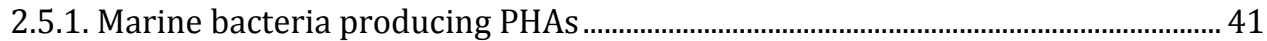

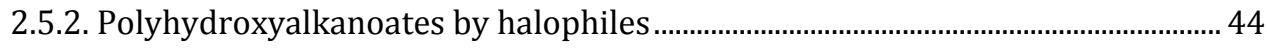

2.5.3. PHA production in halophilic archaea .................................................................... 44

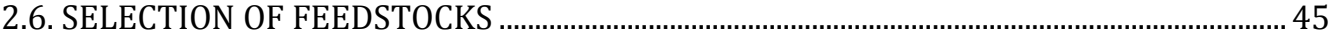

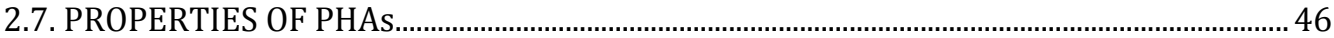

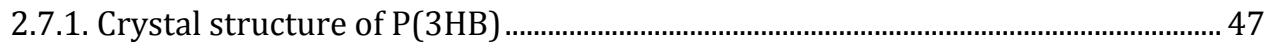



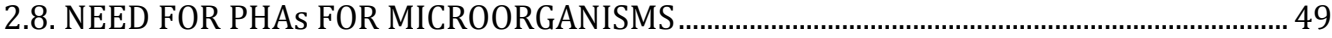

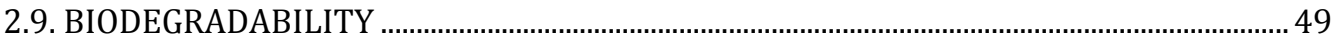

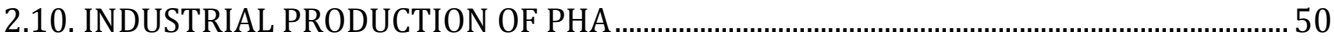

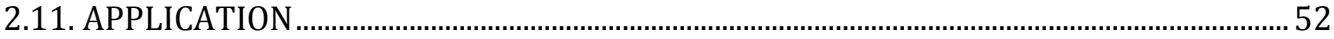

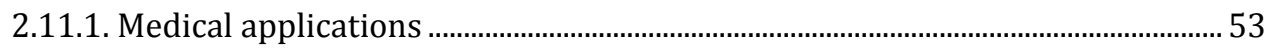

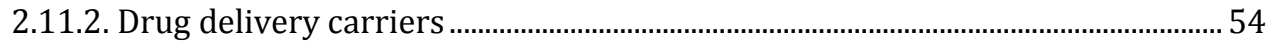

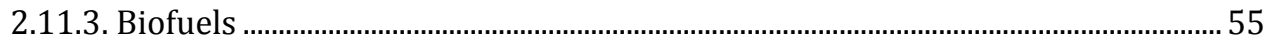

2.12. CONCLUSION AND FUTURE PERSPECTIVES ….................................................................... 55

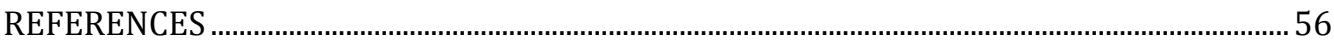




\subsection{INTRODUCTION}

Petroleum derived plastic (polymer) is the most useful extraordinary versatile synthetic polymer with numerous advantages for humans. The human-made synthetic plastic was first discovered in 1862 by Alexander Parkes at the Great International Exhibition in London. This discovery is a breakthrough process in chemistry as man-made synthetic polymers from petrochemicals, which play a vital role in different aspects of everyday life and serve as an indispensable part of human life and have replaced most materials in modern life [1-3]. The last 3-4 decades had tremendous technology development that has catastrophically increased plastic production due to its excellent qualities such as cheapness, light weight, being very stable in harsh condition, and resistance to the microbial decomposition and chemical degradation [4]. During 2010-2015, 300 million tons of plastic was produced yearly worldwide whereas China alone produced $23.9 \%$ of world's total production of plastic and ranks top [5,6]. Though it possesses lots of excellent properties, it also causes many major environmental problems. As most plastics persist in the environment, it takes hundreds of years to degrade and during the degradation process they release plenty of toxic substances like bisphenol A, styrene, polystyrene, and so forth.

The unhindered extensive use of non-degradable petroleum based products (polyethylene, polypropylene, and poly(vinyl alcohol)) leads to the accumulation of toxic waste materials across the planet and affects the survival of many species and causes release of hundred million tons of $\mathrm{CO}_{2}$ into environment each year $[7,8]$. The first alarming report against plastic usage by Carpenter et al. warned that plastic pellets are suspended in the surface of North Atlantic Sea and points out clearly in Science that "the increasing production of plastic, combined with present waste-disposal practices, will probably lead to greater concentrations of plastics on the sea surface" [9]. To overcome these problems several researchers had tried to find several alternative ways like microbial degradation of plastic [10]. Microbial degradation of plastics is a complex process and it requires optimal environment condition and selection of strain (oxidative enzymes production) required for the growth of microbes, which in turn degrades the plastic in a greener way [11]. Recently increasing awareness about environmental plastic pollution stirs research towards finding a replacement of conventional plastics (Figure 1). To address this environmental problem many countries are trying to discover a novel material that can eliminate pollution problems. 


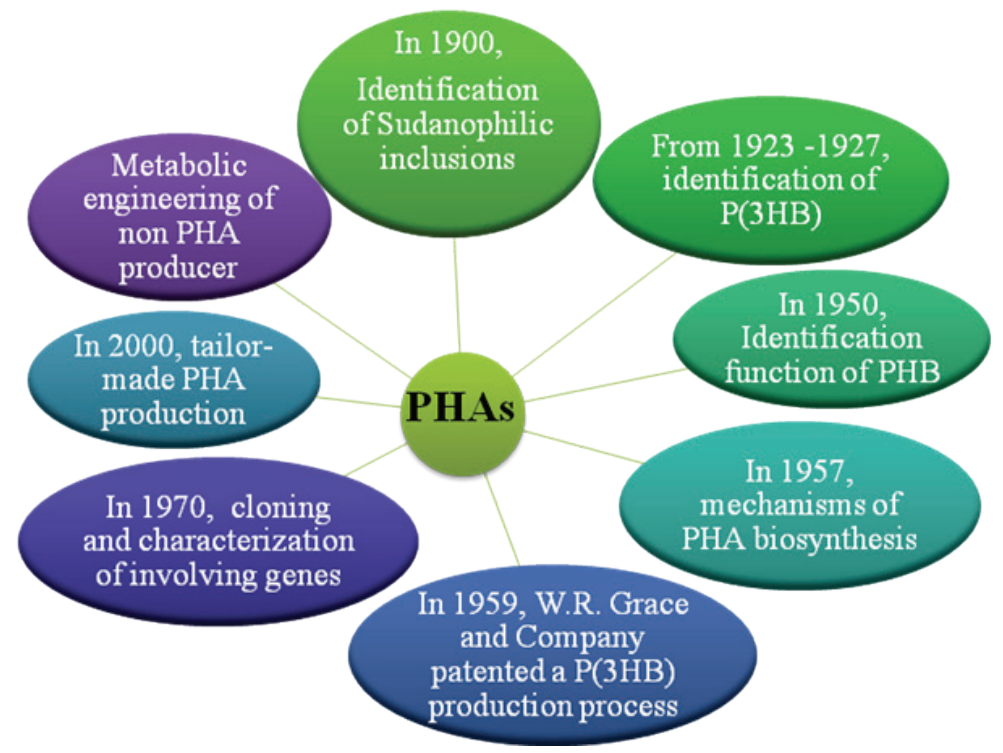

Figure 1. The development of PHAs

\subsection{BIOPOLYMER}

In the course of recent years, biobased plastics have been produced as the cost of petroleum is uphill and petroleum based plastics cause numerous ecological concerns related to plastic contamination. Progressively, diminishment of carbon dioxide emanations has turned into another explanation behind advancing biobased plastics in the midst of the overall money related tidal wave. Generally regarding bioplastics production, the raw materials were mainly gained from three types of renewable source agricultural, forestry, and industrial wastes. The biobased plastics are classified into three types based on the source, chemically synthesized polymer, starch based polymers, and polyhydroxyalkanoates (PHAs). Chemically synthesized polymers are not suitable as substitute for plastics as they are susceptible to enzymatic or microbial attack and are not commercially viable. Starch based polymers use conventional plastic (polyethylene, polypropylene, and poly(vinyl alcohol)) with the mix of starch as fillers and crosslinkers; thus they could take lot of time to get partially degraded and the remains create environmental pollution [12]. By contrast, the PHAs are the only polymer that can be degraded to an extent of $100 \%$, which are produced by microbes in the presence of rich carbon source and essential minerals like phosphorus or nitrogen are limited. PHAs can be completely degraded into water and carbon dioxide in aerobic condition and as methane in anaerobic condition by microorganism's existence in soil, water, and sewage. Similarly PHB has all the physical properties 
equivalent to conventional plastic but the only disadvantage is PHB's high production cost.

\subsection{MARINE ENVIRONMENT POLLUTION DUE TO PLASTICS}

Technology development and exploitation of natural resources eventually result in the pollution of environment; however, plastic pollution is the manmade environmental problem in sea surfaces, estuaries, shorelines, and depths of the oceans with the result to annihilate the marine habitants [8]. Alarming rates of marine pollution were critically assessed $[4,13,14]$. This uncontrolled marine plastic pollution possesses huge toxicological issues that need to be addressed. The relationship between the excessive plastic pollution and that of cancer is unknown; the dosage that could lead to this disease and its epidemiological evidence are to be found [15]. The plastic reaches ocean directly by people dumping it in sea sources or indirectly by numerous ways (beaches, rivers, sewage discharge, storm water runoff, transport by wind, and being accidently lost in several ways). Currently 300 million tons of synthetic plastic has been manufactured every year and almost 5-13 million tons of plastic ends up in ocean [16]. As per report based on six years, plastics contamination in oceans has been estimated to be approximately 269,000 tons and has been obtained from the sea surfaces in the form of macro (fishing nets, large hunks of trash, and packing materials) from the Atlantic and Indian Oceans. Plastic pollution in oceans is majorly termed as microplastic and mesoplastics based on the size of the plastic dumped. Microplastics refer to plastic debris of size ranges from 0.06 to $0.5 \mathrm{~mm}$ in diameter, and the plastic debris other than the specified limit is termed as mesoplastics. Microplastic pollution is the major pollutants in marine environment compared to the mesoplastics and is comparatively difficult to remove from the surface of ocean and is very harmful to marine environment. However, unacceptable amount of microplastics is sunk into deep oceans. Increasing evidence on risk about the plastic contaminations in marine projects (National Oceanographic and Atmospheric Administration, US (NOAA)) and the European Marine Strategy Framework Directive (MSFD, 2008/56/EC) has contributed to political decisions in monitoring marine plastic contamination [17].

Notably plastics are fragmented into small pieces $(<5 \mathrm{~mm})$ [18], and the reason for scrutinizing the microplastics is that they are small pieces of plastics debris that are not visible with the naked eye and could easily enter into the microbial food chain [19]. Occurrence of the microplastics not only is a major problem, but also can sorb various environmental pollutants like polycyclic aromatic hydrocarbons (PAHs), heavy metals, organochlorine pesticides, petroleum hydrocarbons, polybrominated diphenyl ethers, bisphenol $\mathrm{A}$, and alkylphenols [20-24]. Microplastics have some physical properties like being 
less denser than sea water and hence could easily move around [25], form sediments in the deep sea by biofouling [26], and accumulate into various marine organisms $[27,28]$. At present the impact of plastic debris on marine life has been extensively reviewed; particularly 340 original papers were reported on the encounters between organisms and marine debris in about 693 species. Plastic debris accounts for $92 \%$ of all reported pollution encounters between debris and individuals. Based on the International Union for Conservation of Nature (IUCN) Red List, about $17 \%$ of species are affected by entanglement and ingestion, and this list of organisms was reported [29]. Plastic debris ingestion is harmful to marine [30] and there are several literatures available on its effects on birds, turtles, and fish [31]; new invasive species enter and form new habit colonization [32] and change physical habits $[33,34]$.

\subsection{BIOPOLYMER FROM MICROORGANISMS}

Bacterial PHAs comprise a special type of biopolymer lipid like inclusion in cytoplasm. More than 300 species of Gram-positive and Gram-negative bacteria were identified as a reserve energy material under phosphorus or nitrogen limiting concentration with excess of carbon sources [35,36]. In the early $20^{\text {th }}$ century, [37] the presence of lipid like inclusion was found in Azotobacter chroococcum. Later similar chemical composition (3hydroxybutyric acid) ( $\mathrm{P}(3 \mathrm{HB})$ ) was identified in Bacillus megaterium by a French microbiologist $[38,39]$. Williamson and Wilkinson (1958) indicated that accumulation of $\mathrm{P}(3 \mathrm{HB})$ is an intracellular reserve carbon and energy material in Bacillus sp. [40], after that in 1974, Wallen and Rohwedder identified hydroxyalkanoate (HA) other than 3HB [41]. The HA units 3-hydroxyvalerate (3HV) and 3-hydroxyhexanoate (3HHx) were identified in chloroform extract of activated sludge in major and minor constituents; a decade later heteropolymers were identified in marine sediments, which were analyzed by utilizing capillary gas chromatography explored $3 \mathrm{HB}$ and $3 \mathrm{HV}$ as a major in 11 other HA units [42].

In 1983, Smet and coworkers made an interesting finding while they were cultivating Pseudomonas oleovorans on $n$-octane [43], the discovery of HA units other than $3 \mathrm{HB}$ in microorganisms. PHA proved to have gained major significance on the research and commercial interest for this bacterial reserve polymer. This discovery has therefore highlighted as an application the incorporation of a second monomer unit into $\mathrm{P}(3 \mathrm{HB})$, which signifies the beginning of the second developmental stage of research on PHA. By the end of the 1980s, ultimately discovery of various HA units by several researchers [44], including 4HA [45] and 5HA [46], was made. At the same time, storage polymer production was not only seen in Gram-negative but also in Grampositive bacteria, anaerobic (non-sulfur and sulfur purple bacteria) and 
aerobic (cyanobacteria), and also in some archaebacteria [47,48]. So far approximately 150 different monomers of various structures (saturated, unsaturated, branched, straight, and aromatic) of over 90 genera have been reported $[49,50]$.

In the early 1970s, after the dawn of molecular biology techniques, researchers found the genes responsible for the synthesis of PHAs and decipher genetic information and characters in it. In the late 1980s, researchers have cloned the enzymes involved in the biosynthetic pathway from Ralstonia eutropha and obtained functionally active enzymes from $E$. coli. Using metabolic engineering approaches, many researches had developed novel PHA homopolymers and this was a new opportunity for polymer production [51-53]. These types of polymers are accumulated as intracellular granules in their cytoplasm with varying size, number, monomer composition $(>100)$, and molecular mass $50,000-1,000,000$ Dalton (Da) that are dependent on the organisms $[47,54]$. The size of the granules ranges from 0.2 to $0.5 \mu \mathrm{m}$, which can be clearly visualized by high refractivity in light microscope using staining dyes (Sudan Black B and Nile Blue A or Nile red), PHAs can accumulate $80 \%$ in their cell weight $[55,56]$. Among all characterized PHAs, alkyl groups that contain R configuration at C-3 vary largely from 1 carbon to 14 carbons in length. Basically classification of PHAs is based on carbon atoms present in it; monomers containing up to five carbons are classified as short chain length PHAs (scl-PHAs, e.g., poly(3-hydroxybutyrate) P(3HB), poly(4hydroxybutyrate) $\mathrm{P}(4 \mathrm{HB})$, and poly(3-hydroxyvalerate) $\mathrm{P}(3 \mathrm{HV})$ or the copolymer poly(3-hydroxybutyrate-co-3-hydroxyvalerate) (P(3HB-co-3HV)) and PHAs containing 6-14 carbon are classified as medium chain length (mclPHAs, e.g., 3-hydroxyhexanoate) $\mathrm{P}(3 \mathrm{HHx})$, poly(3-hydroxyoctanoate) $\mathrm{P}(3 \mathrm{HO})$, and copolymers such as $\mathrm{P}(3 \mathrm{HHx}-\mathrm{co}-3 \mathrm{HO})$ [56]. Lemoige (1926) has first described the composition of intracellular granules of poly(3-hydroxybutric acid) $\mathrm{P}(3 \mathrm{HB})$ as unknown molecule [38], which is in the form of homopolyester, and Macrae and Wilkinson (1958) first reported the function of poly( $\beta$-hydroxybutyrates) (PHB) and also said that it is biodegradable in Bacillus megaterium bacteria, and, after this report, the interest in PHAs grew eventually and biopolymer research had been started [57]. Among the PHAs member, PHB is most studied and well characterized one [55,56]. Figures 2 and 3 show general structure of PHA and PHB. 


$$
\begin{array}{ll}
n=1 & \mathrm{R}=\text { hydrogen-poly(hydroxy propionate) } \\
& \mathrm{R}=\text { methyl-poly(3-hydroxybutyrate) } \\
& \mathrm{R}=\text { ethyl-poly(3-hydroxyvalerate) } \\
& \mathrm{R} \text { =propyl-poly(3-hydroxyhexanoate) } \\
& \mathrm{R} \text { =pentyl-poly(3-hydroxyhexanoate) } \\
& \mathrm{R}=\text { nanoyl-poly(3-hydroxydodecanoate) } \\
& \mathrm{R}=\text { hydrogen-poly(4-hydroxybutyrate) } \\
n=2 & \mathrm{R}=\text { methyl-poly(4-hydroxyvalerate) } \\
& \mathrm{R}=\text { hydrogen-poly(5-hydroxyvalerate) } \\
& \mathrm{R}=\text { = methyl-poly(5-hydroxyhexanoate) }
\end{array}
$$<smiles>[R]C(O)CC(=O)OC([R])CC(=O)OC(O)CC(=O)O</smiles>

Figure 2. General structure of PHA

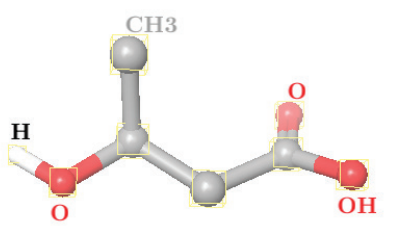

Figure 3. 3D structure of PHB

\subsection{MARINE BACTERIA POTENTIAL}

In our planet earth, microorganisms play very crucial role in maintaining the ecosystem and are capable of adapting to the environmental changes all across the world and could also survive in extreme conditions that prevail even in volcano or Antarctic conditions and make marine environment more favorable condition for survival. Oceans cover around $71 \%$ of earth surfaces, in which $97 \%$ of it is saline water and terrestrial microbe is quite potential microbe and is isolated from the marine sources and it provides endless purposes like bioremediation and bioactive compounds. The main reason behind marine microbes being a potential candidate for bioremediation is the harsh 
environment where it survives. This environment change is mostly man-made due to the urbanization and some prevail in nature; this affects the river flow modification transporting various pollutants to marine sources. There are several factors influencing the harsh environment that exist in marine condition like the high salinity, fluctuation of temperature, $\mathrm{pH}$, alkaline or acidic, changes in exposure of UV, and other man-made harms that include dumping of waste which alters the marine environment to a greater extent [58]. Exposure of bacteria to such extreme condition alters the bacteria to genetic level and adapts using some unique mechanism to survive like biofilm formation [59] and production of biosurfactants [60], thus changing amino acid pathway, methionine pathways, and lipid and glycogen metabolism [61]. Consequently organisms that survive such hostile conditions have better adaptability and thus bacteria could also survive extreme conditions that subsist in bioremediation ambiance.

\subsubsection{Marine bacteria producing PHAs}

Marine environment has been explored to harbor potential PHBs producing strain (Table 1); their potential depends on enzymes they produce, which results in the adaptability to conditions like cold adaptivity or barophilicity, hyperthermal stability, and high salt tolerance that cannot be done by terrestrial bacteria [96]. Marine bacteria grow faster and are capable of accumulating wide varieties of PHAs so they have the potential for industrial applications. According to Gouffi et al. and Hua et al., presence of salinity stress (ionic and osmotic) has been inducing the accumulation of PHAs in intracellular localization by adjusting the concentration of higher inorganic ions ( $\mathrm{N}, \mathrm{K}$, or other ions), low organic solutes or increasing stress proteins, amino acids, potassium, betaines, or carbohydrates to equilibrate osmotic pressure $[97,98]$. All the four salt tolerant rhizobial strains were able to tolerate varied $\mathrm{NaCl}$ concentrations $(0-1000 \mathrm{mM})$ and subsequently bacterial PHB accumulation was analysed; PHB was found at higher $\mathrm{NaCl}$ concentrations. In higher PHB accumulation was observed in higher salt tolerant strains because the PHB accumulation is closely related to the unfavorable conditions (non-carbon nutrients such as $\mathrm{N}, \mathrm{P}, \mathrm{K}$, or $\mathrm{O}_{2}$ ) [99]. Similar result was also observed in the accumulation of PHBs in their cells in osmotic pressure [47]. The advantage of marine bacteria as a source of biosynthesizing PHA production in marine condition is to avoid contamination from salt-water resistance microbes and marine water is directly filtered and used as industrial large scale medium for production of PHAs [66]. In 1971, 143 marine strains had isolated genus of Beneckea and 3 strains were capable of producing PHB and first ever to be reported from marine source [62]. 
Table 1. PHAs producing marine bacteria

\begin{tabular}{|c|c|c|}
\hline Bacteria & Type of PHAs & Author and year \\
\hline B. nereida & PHB & [62] \\
\hline B. natriegens & PHB & \\
\hline Vibrio algosus & PHB & [63] \\
\hline V. marinofulvus & PHB & \\
\hline V. alginolyticus & PHB & \\
\hline V.parahaemolyticus & PHB & \\
\hline V. marinus PS-207 & PHB & \\
\hline V. cholerae & PHB & \\
\hline Agrobacterium stellulatum & PHB & \\
\hline Achromobacter aquamarinus & PHB & \\
\hline Spirillum linum & PHB & \\
\hline Pseudomonas perfectomarinus & PHB & \\
\hline P. aeruginosa & PHB & \\
\hline Photobacterium fischeri & PHB & \\
\hline Arthrobacter marinus & PHB & \\
\hline Azotobacter vineladii & PHB & {$[64]$} \\
\hline Vibrio harveyi & PHB & [65] \\
\hline Escherichia coli & PHA & {$[66]$} \\
\hline Alcaligenes latus & PHB & {$[67]$} \\
\hline Acinetobacter sp. & PHA & {$[68]$} \\
\hline Haloferax mediterranei & PHA & {$[69,70]$} \\
\hline Desulfococcus multivorans & PHA & {$[71]$} \\
\hline Haloferax mediterranei & PHA & {$[72]$} \\
\hline H. mediterranei & PHBV & {$[73]$} \\
\hline H. mediterranei & PHA & {$[74]$} \\
\hline Vibrio sp. & PHB & [75] \\
\hline H. mediterranei & PHA & [76] \\
\hline Saccharophagus degradans & PHAs & [77] \\
\hline Microcoleus chthonoplastes & PHB & [78] \\
\hline Lyngbya aestuarii & PHB & \\
\hline Leptolyngbya sp. & PHB & \\
\hline Oscillatoria sp. & PHB & \\
\hline Geitlerinema sp. & PHB & \\
\hline Gloeocapsa sp. & PHB & \\
\hline Pseudomonas guezennei sp. & PHA & [79] \\
\hline
\end{tabular}


Table 1. (continued)

\begin{tabular}{|c|c|c|}
\hline Bacteria & Type of PHAs & Author and year \\
\hline H. mediterranei & PHB & {$[80]$} \\
\hline Pseudomonas extremaustralis & PHB & [81] \\
\hline Vibrio sp. & PHB & [82] \\
\hline Bacillus cereus & PHB & \\
\hline Bacillus mycoides & PHB & \\
\hline Bacillus sonorensis & PHA & [83] \\
\hline Halomonas hydrothermalis & PHA & \\
\hline Pseudoaltermonas sp. & PHA & [84] \\
\hline Bacillus megaterium & PHB & [85] \\
\hline Vibrio sp. & PHB & [86] \\
\hline Vibrio sp. & PHA & [87] \\
\hline Bacillus subtilis & PHB & [88] \\
\hline Colwellia spp. & PHA & [89] \\
\hline Moritella spp. & PHA & \\
\hline Shewanella spp. & PHA & \\
\hline Bacillus megaterium & PHB & {$[90]$} \\
\hline Vibrio azureus & PHB & [91] \\
\hline Bacillus sp. & PHA & {$[92]$} \\
\hline Oceanimonas sp. & PHA & [93] \\
\hline Bacillus megaterium & PHA & [94] \\
\hline \multirow[t]{2}{*}{ Bacillus sp. } & PHB & [94] \\
\hline & PHB & \\
\hline Shewanella sp. & PHB & [95] \\
\hline
\end{tabular}

After that, several researchers studied the PHB production from marine bacteria; for example, Oliver and Colwell (1973) have reported on 20 marine species that accumulate PHB [63]; Alvarez et al. isolated the lipid storage compounds from marine bacteria [68] and Sun et al. reported on the discovery of PHB from luminescent bacterium Vibrio Harveyi [65]. From $20^{\text {th }}$ century, several researchers focused on the biopolymer production from marine bacteria; accumulation of PHA from sulfate-reducing bacteria and PHB; and using different carbon source sources including acetate, glucose, glycerol, succinate, and sucrose. Arun et al. isolated 42 marine bacteria from south India and finalized four potential PHB producing bacteria (two Vibrio sp. Bacillus cereus, and Bacillus mycoides) [82]. They have investigated better carbon, nitrogen substrates, $\mathrm{pH}$, and salt concentration for fermentation (carbon source: arabinose, glucose, glycerol, lactose, lactic acid, mannitol, sodium acetate, starch, and sucrose; nitrogen source: ammonium chloride, ammonium 
sulphate, glycine, potassium nitrate, protease peptone, and urea) $\mathrm{pH}$ levels (2-9), different salt concentrations (5-30\%) for better productivity. In these fermentations studies, maximum of $9.1 \mathrm{~g} \mathrm{~L}^{-1}$ was obtained in the production of $4.223 \mathrm{~g} \mathrm{~L}^{-1}$ of PHB; at the same time ammonium sulphate $(90 \%)$ and glucose (71.85\%) were metabolized [82].

Pandian et al. first attempted the use of raw sea water as a source of minerals as well as key nutrient for PHB production, which is an easily available cheapest source for bacteria growth [85]. The PHAs production cost mainly depends on the substrates used for production, nearly accounting for 30-40 \% of total cost of the PHB.

\subsubsection{Polyhydroxyalkanoates by halophiles}

Microorganisms that require high salt concentration in the environment for their growth are termed as halophile. Most halophiles grow at optimum cell growth and tolerate 5-10\% (w/v) salt concentration [100]. Halophiles are found in all the three domains of life; they basically adapt two different metabolic pathways to survive on this high salt concentration; the first is to regulate concentrations of $\mathrm{KCl}$ with that of $\mathrm{NaCl}$ in the external environment, thus maintaining the osmotic pressure and enhancing survival [100,101]. Some haloalkaliphilic bacteria such as Natronococcus occultus and N. gregoryi use 2-sulfotrehalose instead of $\mathrm{KCl}$ to some extent to counterbalance these external stimuli when cultured in nutrient limited medium [102]. The second adaptation is similar to that of the earlier one whereas bacteria and eukarya maintain low concentration of salt by accumulating low molecular weight organic compounds known as osmolytes [100,101]. Osmolytes are compatible solutes which are mostly amino acids, derivatives, sugars, or polyols that by and large do not interfere in the metabolism of the cell. This osmolyte facilitates retaining turgor pressure, cell dimensions, and the concentration of electrolytes that are vital for the cell to be biologically active [101]. Halophilic bacteria include a huge number of phylogenetic groups akin to cyanobacteria, spirochetes, and actinomycetes, where some of them can withstand $\mathrm{NaCl}$ concentration of $30 \%(\mathrm{w} / \mathrm{v})[100]$.

\subsubsection{PHA production in halophilic archaea}

The first report of PHA accumulation in archaea was made by Kirk and Ginzburg during the characterization of halophilic strains [103]. Haloferax mediterranei is the best PHA producer ever reported with $65 \mathrm{wt}$ \% PHA in dried cell weight when cultured in starch or glucose as the only carbon source with phosphorous as limiting condition [69,104]. Moreover, $46 \mathrm{wt}$. \% could be obtained in continuous fostering in bioreactor provided this could be done only during active cell growth and not for bacteria accumulating PHA in their stationary phase [105]. A recent report suggests that the chemical structure of PHA produced by $\mathrm{H}$. mediterranei is similar to the copolymer $\mathrm{P}(3 \mathrm{HB}-\mathrm{co}-3 \mathrm{HV})$ 
[72] and the copolymer synthesis from carbohydrate is very rare in microorganisms, whereas PHB would be the usual product formed. The advantage over $\mathrm{P}(3 \mathrm{HB}-\mathrm{co}-3 \mathrm{HV})$ is that $\mathrm{PHB}$ would be more elastic with less crystalline nature that eliminates the brittle problem, tougher, and flexible for material processing and have lower melting point than the latter [106]. The PHA productivity varies mostly depending upon the provided carbon source, when glucose is present in the culture and $48.6 \mathrm{wt}$ \% could be produced with volumetric productivity of $0.36 \mathrm{~g}^{-1} \mathrm{~L}^{-1} \mathrm{~h}^{-1}$. Similarly while replacing the glucose with corn starches, the volumetric productivity was decreased to 0.29 $\mathrm{g}^{-1} \mathrm{~L}^{-1} \mathrm{~h}^{-1}$ [73]. However, the productivity is increased to considerable level when a mixture of extruded rice bran and corn starch $(1: 8 \mathrm{w} / \mathrm{w})$, say 0.71 $\mathrm{g}^{-1} \mathrm{~L}^{-1} \mathrm{~h}^{-1}$, was obtained [74].

\subsection{SELECTION OF FEEDSTOCKS}

The production of PHAs in industrial scale is a promising remedy for the environmental hushes caused by the abuse of synthetic plastics. There are some of nutrients rich media that can be essential during the growth phase of bacteria and certain limiting nutrients like phosphorus, nitrogen, and so forth are vital for the biosynthesis of PHAs. However, biosynthesis of PHAs mainly depends on carbon substrates for microbial growth and their metabolism to convert the precursor material [107]. Fortunately, growth medium is the only limiting material that decides the cost of PHAs production. In recent years, the use of industrial by-products having surplus energy as feedstock is preferred compared to the traditionally used raw materials that are expensive. A wide range of industrial by-products has been used for PHAs production like agricultural, household waste materials, sugars, lignocellulosic raw materials, fats, and oils. Among those, extensive research is focused on wastes, sucrose [108], starch [109], glucose [110-112], soy molasses and hydrolysed soy $[113,114]$, sugar cane molasses [115-117], waste rapeseed oil [118, 119], sunflower meal hydrolysates [120], glycerol [121,122], rice bran and corn starch [74], lard oil, butter oil, and coconut oil [123], palm oil and its products [124], sugar beet molasses [125], spent palm oil [126], cellulose and cellulose hydrolysates [127], sugarcane bagasse hydrolysates [128,129], casein hydrolysate [130], rapeseed meal hydrolysates [131], triacylglycerides (TAG) [132], sugarcane liquor [133], acetic acid [111,134], corn steep liquor [135], fish peptone medium [136], galactose, mannose and rhamnose [137], cheese whey and hydrolysed whey[115,138,139], urea [117], oil [124], wheat based biorefinery [140,141], xylose [128], arabinose [142], fructose [143], lactic acid [144], oleic acid [145], corn oil [146], vegetable oil waste [147], crude Jerusalem artichoke hydrolyzate [148], gaseous mixture of $\mathrm{H}_{2}, \mathrm{O}_{2}$, and $\mathrm{CO}_{2}$ [70], biodiesel waste water [149], paper mill wastewater [150], palm oil mill effluents [151], starchy wastewater [152], and municipal waste waters [153] and sometimes specialized carbon source used 4-hydroxybutyric acid, 
1,4-butanediol, and butyrolactone [154] as the raw material for the synthesis of PHAs.

\subsection{PROPERTIES OF PHAS}

PHAs have different structural composition of the monomer and considerably vary in physical and chemical properties based on their crystallinity, transition temperature, melting point, and hydrophobicity (Table 2). PHAs families are classified into two types: (a) short chain length PHAs (PHAscl) which contain 3-5 carbon atoms (poly-3-hydroxybutyrate (P3HB) and poly-4 hydroxybutyrate (P4HB)) and medium chain length PHAs (PHAmcl) contain 6-14 and more than carbon atoms (poly(3-hydroxyhexanoate) $\mathrm{P}(3 \mathrm{HHx})$ and poly(3-hydroxyoctanoate) $\mathrm{P}(3 \mathrm{HO})$ [156]. Long chain length (PHAlcl) contain above 14 carbon atoms. Difference between the monomer compositions of PHAs is due to their carbon substrates specificity of producing microorganism. What especially discriminate the PHAscl from mcl-PHAs monomer are low glass transition temperatures $\left(-30\right.$ to $-40{ }^{\circ} \mathrm{C}$ ), broad melting range (around $60^{\circ} \mathrm{C}$ ), and low degree of polymerization (molecular masses below $100,000 \mathrm{Da}$ ); the high-glass transition temperature is around $0^{\circ} \mathrm{C}$, sharp melting point is up to $180^{\circ} \mathrm{C}$, and molecular mass is up to $\mathrm{MDa}$ [3].

Apart from the general classification of side chain length, there are different types of side chain functional groups attached to PHAs family. The presence of 3-hydroxyl group and the carboxylic groups allows the further modification, for example, phenoxy, cyanophenoxy, halogens, carboxyl, hydroxyl, epoxy, methyl ester, and thiophenoxy groups [156]. Among the PHAs, $\operatorname{poly}(\beta-$ hydroxybutyrates) (3-hydroxybutyric acid) is the first discovered homopolymer, with wide varieties of microbes accumulated and has most similar properties to that of polypropylene. Sometimes few reports are related to non-PHB homopolymers, including P4HB [157,158], poly(3hydroxypropionate) (P3HP) [159], poly(3-hydroxy-5-phenylvaleric acid) [47], poly(3-hydroxyvalerate) (PHV) [160], poly(3-hydroxyhexanoate) (PHHx) [47,133], poly(3-hydroxyoctanoate) (PHO) [161], poly(3-hydroxyheptanoate) (PHHp) [161], poly(3-hydroxydodecanoate) (PHDD) [162], poly(3hydroxydodecanoate) (PHD), and poly(3-hydroxynonanoate) (PHN) [163]. 
Table 2. Comparison of the physical properties of different PHAs with conventional petroleum-based polymers [172-174]

\begin{tabular}{|c|c|c|c|c|c|}
\hline Polymer & $\begin{array}{c}\text { Young's } \\
\text { modulus } \\
\text { GPa }\end{array}$ & $\begin{array}{l}\text { Tensile } \\
\text { strength } \\
\text { MPa }\end{array}$ & $\begin{array}{c}\text { Melting } \\
\text { temperature } \\
{ }^{\circ} \mathrm{C}\end{array}$ & $\begin{array}{c}\text { Glass } \\
\text { transition } \\
\text { temperature } \\
{ }^{\circ} \mathrm{C}\end{array}$ & $\begin{array}{l}\text { Elongation } \\
\text { at break \% }\end{array}$ \\
\hline $\mathrm{P}(3 \mathrm{HB})$ & $3.5-4$ & 40 & $173-180$ & $5-9$ & $3-8$ \\
\hline $\mathrm{P}(4 \mathrm{HB})$ & 149 & 104 & 53 & -50 & 1000 \\
\hline $\begin{array}{c}\mathrm{P}(3 \mathrm{HB}-\mathrm{co}-3 \mathrm{HV}) \\
(3 \mathrm{~mol} \% 3 \mathrm{HV})\end{array}$ & 2.9 & 38 & 170 & n.a & n.a \\
\hline $\begin{array}{l}\mathrm{P}(3 \mathrm{HB}-\mathrm{co}-3 \mathrm{HV}) \\
(25 \mathrm{~mol} \% 3 \mathrm{HV})\end{array}$ & 0.7 & 30 & 137 & n.a & n.a \\
\hline $\begin{array}{c}\mathrm{P}(3 \mathrm{HB}-\mathrm{co}-4 \mathrm{HB}) \\
(3 \mathrm{~mol} \% 4 \mathrm{HB})\end{array}$ & n.a & 28 & 166 & n.a & 45 \\
\hline $\begin{array}{l}\mathrm{P}(3 \mathrm{HB}-\mathrm{co}-4 \mathrm{HB}) \\
(90 \mathrm{~mol} \% 4 \mathrm{HB})\end{array}$ & 100 & 65 & 50 & -42 & 1080 \\
\hline $\mathrm{P}(3 \mathrm{HHx}-\mathrm{co}-3 \mathrm{HO})$ & n.a & 10 & 61 & n.a & 300 \\
\hline $\begin{array}{c}\mathrm{P}(3 \mathrm{HB}-\mathrm{co}-3 \mathrm{HA}) \\
(6 \mathrm{~mol} \% 3 \mathrm{HA})\end{array}$ & 0.2 & 17 & 133 & -8 & 680 \\
\hline $\begin{array}{l}\mathrm{P}(3 \mathrm{HB}-\mathrm{co}-\mathrm{HP}) \\
(67 \mathrm{~mol} \% \mathrm{HP})\end{array}$ & n.a & n.a & 44 & -19 & n.a \\
\hline $\begin{array}{c}\text { Isotactic } \\
\text { polypropylene }\end{array}$ & $1.0-1.7$ & $29.3-38.6$ & $170-176$ & -10 & $500-900$ \\
\hline HDPE & $0.4-1.0$ & $17.9-33.1$ & $112-132$ & -80 & $12-700$ \\
\hline LDPE & $0.05-0.1$ & $15.2-78.6$ & 88-130 & -36 & $150-600$ \\
\hline Nylon-6,6 & $3.0-3.1$ & 50 & $80-110$ & 21 & $3-4$ \\
\hline $\begin{array}{l}\text { Polyethylene- } \\
\text {-terethalate }\end{array}$ & 2.2 & 56 & 262 & 3400 & 7300 \\
\hline
\end{tabular}

Note: n.a. not available

\subsubsection{Crystal structure of $\mathbf{P}(3 \mathbf{H B})$}

The crystal structure of $\mathrm{P}(3 \mathrm{HB})$ has been determined using X-ray studies from oriental fibers. There are two different forms of crystal: $\alpha$ form as regular crystals and $\beta$ form as crystals formed by strain-induced paracrystalline structure with extended chain and twisted planner zigzag conformation. A single orthorhombic unit cell with dimension of $a=0.576 \mathrm{~nm}, b=1.320 \mathrm{~nm}$, and $c=0.596 \mathrm{~nm}$ and the space group of $\mathrm{P} 2{ }_{1} 2{ }_{1} 2_{1}$ consists of two molecules in anti-parallel fashion. The cell dimension remains the same for both $\alpha$ and $\beta$ form of crystals. The $\beta$ form crystal can be converged back to $\alpha$ form when the temperature is increased to $130^{\circ} \mathrm{C}$ with a slight increase in crystallinity. In $\alpha$ form, conformational analysis revealed that the main factor governing the 
molecular packing is dipole-dipole interaction, which is because of the ester groups of the anti-parallel chain. Formation of carbonyl oxygen/methyl interaction favours PHAs to adopt helical conformation [164]. This structure is stabilized by bipolar interaction between anti-parallel helical chains with the ester moieties without the need for any hydrogen bonding as of proteins [44]. The $\beta$ form was first reported by [165] in a stretched $\mathrm{P}(3 \mathrm{HB})$ film. The difference between $\alpha$ and $\beta$ form is that the latter is completely extended chain conformation. The shift to $\beta$ form does not require a prior alignment to the $\alpha$ form lamellae but the orientation of the free chains in amorphous region between crystals [166]. The tie between these lamellar layers of crystal increases its mechanical properties.

The single crystals with well defined structure are the monolamellar form that are reported to be forming in different solvent conditions like chloroform/ethanol, propylene carbonate, poly(ethylene glycol), and so forth [167-170] which were investigated by microscopic analysis to study the surface morphologies and crystal structure. The thickness is dependent on many factors such as molecular weight, solvent, and crystallization temperature. The analysis revealed that the crystals are lath shaped with typical dimension of around $0.3-2 \mu \mathrm{m}$ for short and 5-10 $\mu \mathrm{m}$ for long axis and the thickness of the crystal was obtained around $4-10 \mathrm{~nm}$ based on the molecular weight, solvent, and crystallization temperature. The crystals of $\mathrm{P}(3 \mathrm{HB})$ usually form as monolamellar, which gives well defined structures whereas bulk materials such as plates and films form multilamellar crystals. Spherulites are spherical semi-crystalline region in a polymer when the crystals are obtained from the melt in bulk material [167]. The kinetics growth rate of spherulites is optimum around $50-60^{\circ} \mathrm{C}$.

\subsubsection{Physical properties of $\mathbf{P}(3 \mathrm{HB})$}

Most wild type bacteria produce PHAs around the molecular weight ranges between $1 \times 10^{4}$ and $3 \times 10^{6} \mathrm{~g} \mathrm{~mol}^{-1}$ with a polydispersity of about two. The other physical properties like glass transition temperature are around $4{ }^{\circ} \mathrm{C}$ and the melting temperature is about $180^{\circ} \mathrm{C}$ as measured by calorimetric analysis. The density of the material in amorphous state is $1.18 \mathrm{~g} \mathrm{~cm}^{-3}$ and crystal about $1.26 \mathrm{~g} \mathrm{~cm}^{-3}$. Mechanical properties like Young's modulus and tensile strength are about $3.5 \mathrm{GPa}$ and $43 \mathrm{MPa}$, respectively, for $\mathrm{P}(3 \mathrm{HB})$, which are close to the polypropylene; thus it appears stiffer and more brittle material than regular plastic. Much work has been carried out to rule out this problem of brittleness like getting rid of the crack that appears during crystallization by producing the secondary crystals with the reorganization of the lamellar crystals which tightly constrains the amorphous chains in crystals using an annealing treatment after initial crystallization. This problem is also addressed by cloning this gene responsible for the synthesis of the $\mathrm{P}(3 \mathrm{HB})$ in E. coli; harboring genes from $R$. eutropha can produce ultrahigh molecular weight $\mathrm{P}(3 \mathrm{HB})$ homopolymer of range between $3 \times 10^{6}$ and $1.1 \times 10^{7}$ by special 
fermentation conditions [171]. The preparation of stretched films is successful from this ultrahigh molecular weight $\mathrm{P}(3 \mathrm{HB})$ and the physical properties like Young's modulus and tensile strength were improved compared to those of unstretched films of about $1.1 \mathrm{GPa}$ and $62 \mathrm{MPa}$, respectively. In addition, it is found that when the stretched films had undergone annealing treatment, the physical properties are enhanced further. Thus by using the biochemical technique, the quality of $\mathrm{P}(3 \mathrm{HB})$ formed can be improved and further checked for commercial exploitation.

\subsection{NEED FOR PHAs FOR MICROORGANISMS}

A wide variety of microorganisms produce intracellular polymers that act as an intracellular carbon reducing equivalents under nutrient limitation condition [175]. In prokaryotes, different types of genes are cloned and it is found that some putative genes are responsible for the biosynthesis of PHAs. PHB is the more studied polymer in PHAs; in this biosynthetic pathway ketothiolase $(\mathrm{PhaA})$ and acetoacetyl-CoA reductase (PhaB) and $\mathrm{PHA}$ synthase $(\mathrm{PhaC})$ genes are exclusively involved in PHB production metabolism [176].

The necessity for producing intracellular carbon storage compounds by bacteria is subjected to several researches and it is found to play a major role since the polymers act as a reserve storage carbon source in bacteria [177]. PHAs synthesized by bacteria play a major role in bacterial fitness and enhance the survival capabilities under nutrient stress conditions in water and soil [178].

PHAs are biopolymers that are beneficial to bacteria and environment; they are utilized as nutrient under stressful condition in rhizosphere, soil, and phyllosphere [175,179,180-183], distribution of carbon sources [184-187], enhancing survival factors in stress condition; osmotic shock, solvent stress, UV irradiation, heat and cold, ethanol, $\mathrm{H}_{2} \mathrm{O}_{2}$, and desiccation [188-193,183,194196] and control exopolysaccharide production [197,198,191,192,199] play a vital role in different energy consuming pathways, chemotaxis, nitrogen fixation, cell motility and aerotaxis [200,51,183,201,202], formation of cyst, germination, and sporulation [203]. Despite the PAHs producing significant advances, bacterial inoculants currently received much attention in plant growth promotion or plant production [204].

\subsection{BIODEGRADABILITY}

Biodegradability of PHA is mainly due to the enzymes produced in microorganisms, which mostly prevail in various environments soil, marine sediment, lake water, and compost [205-207]. Microbial biodegradation depends on a number of factors such as population of microbes, which 
enhances the microbial activity, environment condition (surface area, nutrient supply, moisture level, $\mathrm{pH}$, and temperature), and PAHs properties (crystallinity, molecular weight, and composition). The rate of biodegradation process is based on properties like crystallinity, stereoregularity (high crystalline has lower biodegradability), and chemical structures (functional group hydrophilicity-hydrophobicity). Most of the studies reported that $85 \%$ of PHAs degrade within seven weeks; in marine environments they are degraded in 254 days with temperature below $60^{\circ} \mathrm{C}$. The rapid hydrolyzation of polymers is done with the help of extracellular depolymerases of bacteria; in aerobic condition the polymers are converted into water and carbon dioxide whereas in anaerobic condition they are converted into methane that can be utilized as a carbon source for the growth [3]. The polymer degrading microorganisms secrete the extracellular enzyme and convert the PHAs into molecular building blocks; a wide variety of extracellular depolymerase enzymes were identified from variety of microbes and the mechanism is well understood [208-212].

Extracellular degradation is done in two steps; that is, they are attachment of enzyme into PHB material followed by hydrolysis; the polymer and surface attachment is based on the Langmuir adsorption equation [213]. Usually in PHB having high crystallinity and melting point, low degradation rate is present. The mechanism of polymer degradation differs in rate based on the environmental condition such as aerobic and anaerobic ones, whereas PHBV degradation is favored by aerobic condition [214,112]. Intracellular depolymerase process is the endogenous carbon reserve source and is very complex due to the intimately connected $\mathrm{P}(3 \mathrm{HB})$ granules. PHAs are biocompatible as they do not release any toxic substances during degradation; several reports show that PHAs are a suitable candidate as a substitute for synthetic plastic due to its ecofriendly nature [174].

\subsection{INDUSTRIAL PRODUCTION OF PHA}

In recent times, the world shifts its dependability towards bioplastic production, so several countries craft policies to stop and control the usage of plastic; for example, Belgium has established eco-tax of $€ 3 / \mathrm{kg}$ of packaging materials and the Netherlands imposed tax on $\mathrm{CO}_{2}$ emissions from plastic production industry. Similarly France, Italy, and Spain are using corresponding legislation [215]. Cumulative research of several years has helped discover PHAs producing bacteria with optimum nutrition condition, inexpensive growth substrates leading to mass production of bioplastic in industrial scale. At present 24 different companies are involved in production of biocompatible PHAs worldwide (Table 3) and around 10,000 varieties of PHAs are available in in the market as in 2009. The first commercial production of PHAs started way back in 1959 by W.R. Grace \& Co in US but it was not successful due to the 
lack of proper purification methods [216]. Subsequently in the 1970s, PHBV was commercialized by Imperial Chemical Industries (ICI) under the trade name of Biopol. At the same time, Chemie Linz, Austria (now Borealis), had joined Petrochemia Danubia (PCD) to produce PHB in pilot scale and later the company was acquired by Biomer, Germany, in the 1980s. Several research groups had started developing different methods for large scale production of PHAs in industrial scale; Procter \& Gamble (P\&G), Meridian, USA, announced 30,000 tons of PHAs production per annum, Usina da Pedra-Acucar e Alcool, Serrana Sao Paulo, produced 10,000 tons of PHAs per annum, and Mitsubishi Gas Chemical (MGC), Japan, produced PHB from methanol under the trade name of BioGreen. China is the world largest PHBV producing country with production of 2000 metric tons per annum; presently China and Japan have dominated the PHA market. The following are some of the most important PHAs in industrial scale: $\mathrm{P}(3 \mathrm{HB}), \mathrm{P}(4 \mathrm{HB}), \mathrm{P}(3 \mathrm{HB}-c o-3 \mathrm{HV})$ poly(3hydroxyvalerate), poly(3-hydroxybutyrate) $\mathrm{P}(3 \mathrm{HB}-\mathrm{co}-4 \mathrm{HV})$ poly(4hydroxyvalerate), and poly(3-hydroxybutyrate-co-3-hydroxyvalerate-co-3hydroxyhexanoate (P(3HB-co-3HV-co-3HHx).

Table 3. Current commercial PHAs producing industries [172,173]

\begin{tabular}{|c|c|c|c|c|}
\hline Company & Country & Types of PHA & $\begin{array}{l}\text { Production } \\
\text { scale }\end{array}$ & Applications \\
\hline $\begin{array}{l}\text { Metabolix } \\
\text { (with } \\
\text { Monsanto) }\end{array}$ & USA & PHBHV and others & n.r. & $\begin{array}{l}\text { packaging } \\
\text { materials }\end{array}$ \\
\hline Tepha Inc. & USA & $\begin{array}{c}\mathrm{P} 4 \mathrm{HB}, \\
\mathrm{P}(3 \mathrm{HB}-c o-4 \mathrm{HB}), \\
m c l-\mathrm{PHA}\end{array}$ & n.r. & $\begin{array}{c}\text { medical } \\
\text { bioimplants }\end{array}$ \\
\hline $\begin{array}{l}\text { Polyferm } \\
\text { Canada }\end{array}$ & Canada & $\begin{array}{c}\text { mcl-PHA (even and } \\
\text { odd numbered, } \\
\text { saturated and } \\
\text { unsaturated } \\
\text { building blocks) }\end{array}$ & kg scale & $\begin{array}{c}\text { packaging, } \\
\text { medical } \\
\text { bioimplants and } \\
\text { others }\end{array}$ \\
\hline $\begin{array}{l}\text { Tianjin } \\
\text { Green } \\
\text { Bioscience } \\
\text { \& DSM } \\
\end{array}$ & China & $\mathrm{P}(3 \mathrm{HB}-c o-4 \mathrm{HB})$ & $10,000 t$ & $\begin{array}{l}\text { packaging } \\
\text { materials }\end{array}$ \\
\hline $\begin{array}{c}\text { PHB } \\
\text { Industrial/ } \\
\text { Copersucar } \\
\text { (PHBISA) }\end{array}$ & Brazil & PHB and PHBHV & $\begin{array}{c}100 \mathrm{t} \\
\text { (capacity } \\
5000 \mathrm{t} \text { ) }\end{array}$ & $\begin{array}{l}\text { packaging } \\
\text { materials }\end{array}$ \\
\hline Biomers & Germany & PHB & unknown & $\begin{array}{l}\text { packaging and } \\
\text { drug delivery }\end{array}$ \\
\hline
\end{tabular}


Table 3. (continued)

\begin{tabular}{|c|c|c|c|c|}
\hline Company & Country & Types of PHA & $\begin{array}{c}\text { Production } \\
\text { scale }\end{array}$ & Applications \\
\hline $\begin{array}{l}\text { ADM (with } \\
\text { Metabolix) }\end{array}$ & USA & several PHA & $50,000 t$ & raw materials \\
\hline Meredian & USA & several PHA & $10,000 \mathrm{t}$ & raw materials \\
\hline Bio-On & Italy & PHA (unclear) & $10,000 \mathrm{t}$ & raw materials \\
\hline $\begin{array}{l}\text { Zhejiang } \\
\text { Tian An }\end{array}$ & China & PHBV & $2,000 t$ & raw materials \\
\hline $\begin{array}{l}\text { Yikeman } \\
\text { Shandong }\end{array}$ & China & PHA (unclear) & $3,000 t$ & raw materials \\
\hline $\begin{array}{c}\text { Jiangsu Nan } \\
\text { Tian }\end{array}$ & China & PHB & pilot scale & raw materials \\
\hline $\begin{array}{c}\text { Shenzhen } \\
\text { O'Bioer }\end{array}$ & China & several PHA & unknown & unclear \\
\hline $\begin{array}{c}\text { Shandong } \\
\text { Lukang }\end{array}$ & China & several PHA & Pilot scale & raw materials \\
\hline $\begin{array}{c}\text { Kaneka } \\
\text { (with P\&G) }\end{array}$ & Japan & several PHA & unknown & packaging \\
\hline $\begin{array}{c}\text { Tianjin } \\
\text { Green } \\
\text { Bio-Science } \\
\text { (+DSM) }\end{array}$ & China & P3HB4HB & 10,000 & $\begin{array}{l}\text { raw materials } \\
\text { and packaging }\end{array}$ \\
\hline
\end{tabular}

Note: n.r. not reported (information not provided by manufacturer)

\subsection{APPLICATION}

PHAs are non-toxic to environment due to the biodegradability and they are a renewable one. They are insoluble in water, with high degree of polymerization, highly crystalline in nature, isotactic, piezoelectric, and optically active. PHAs, owing to diverse properties according to monomer composition, are a pool for several industrial applications (Figure 4). PHAs have immersive attention so they are mainly used in packaging materials, shopping plastic bags, paper coatings, containers, disposable materials (diapers, feminine hygiene products, cups, carpet, cosmetic containers, razors, utensils, upholstery, and lids), medical implant materials, drug delivery carriers, biofuels, and drugs [217]. 


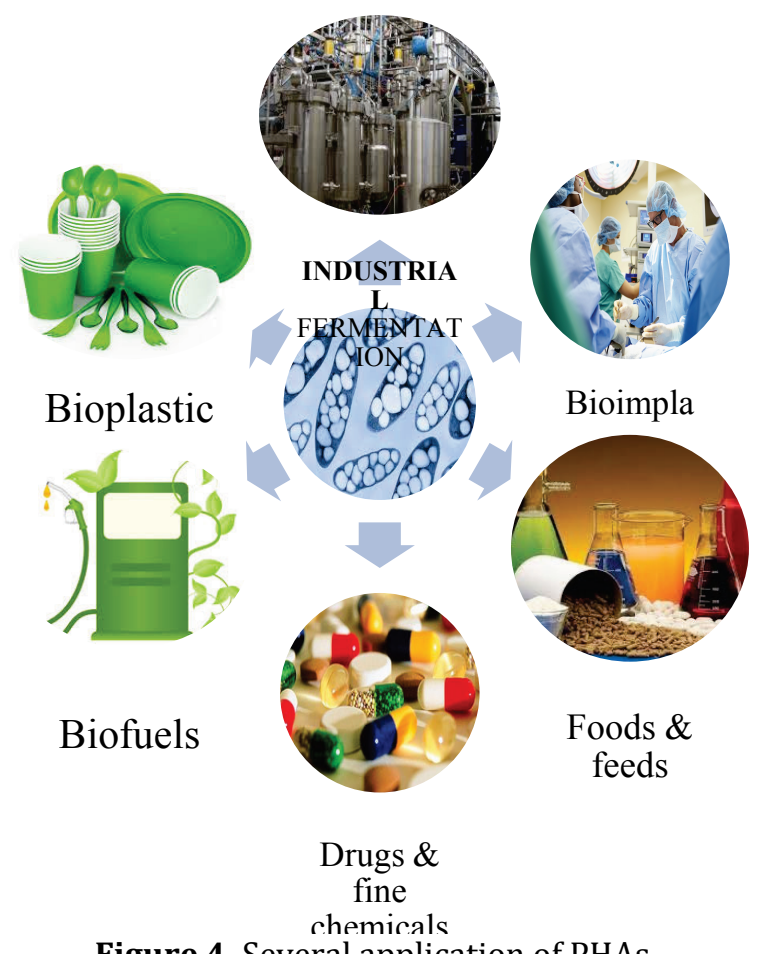

Figure 4. Several application of PHAs

\subsubsection{Medical applications}

Enormous amount of research is being carried out for application of PHAs (PHB, PHBV, P4HB, PHBHHx, and PHO) in biomedical field [218]. For the last two decades, numerous studies had been carried out in lab scale to produce medical devices using PHAs, such as using cartilage replacements, suture fasteners, orthopedic pins (including bone filling augmentation material), bone tissues, surgical mesh, bone plating systems, nerve conduits, meniscus repair, slings, adhesion barriers, heart valves, tacks, bone plates, repair patches, vascular tissues, cardiovascular patches, devices, rivets, staples, screws (including interference screws), esophagus tissues [219], nerve guides [220], atrial septal defect repair devices, tendon repair devices, vein valves, bone marrow scaffolds, spinal fusion cages, ocular cell implants, meniscus regeneration devices, bone dowels, bone graft substitutes, dural substitutes, skin substitutes, ligament and tendon grafts, pericardial patches, bulking and filling agents, wound dressings, and hemostats [221]. The first FDA approved PHAs based Tepha FLEX as absorbable suture was commercialized in 2007; it indicates several new products are awaiting biomedical applications. Polyhydroxyalkanoates and their related technologies are forming an industrial value chain ranging from fermentation, materials, fine chemicals, and energy to medical fields [222]. 
According to Cheng et al., $\mathrm{P}(3 \mathrm{HB})$ promotes the cell proliferation in tissue engineering samples [73]. They have shown that $\mathrm{P}(3 \mathrm{HB})\left(0.02 \mathrm{~g} \mathrm{ml}^{-1}\right)$ accelerates cell proliferation in L929 plated cells at high density $\left(1 \times 10^{5}\right.$ cells/well) but not in the lower densities and also inhibits the cell death. At the same time $\mathrm{P}(3 \mathrm{HB})$ did not affect progression of cell cycle. These treatments prevent the necrosis and permeability of cell membrane.

\subsubsection{Drug delivery carriers}

PHAs can be used as drug delivery carriers due to the biodegradability, biocompatibility, and degradation by surface erosion; thus they can be a potential source for drug carrier molecule. They can be easily modified into porous and thin film materials. The drug delivery is an important application in biomedicine field (anticancer or antiviral); drugs are specifically targeted into particular site and release products at controlled, optimum rate and dosage. Usually homo- and copolymers (lactate and glycolate) are commercially available drug delivery carriers. These polymers consist of targeting moiety, polymeric excipient as carrier, and biologically active agent [223]. Mostly short chain length PHAs are preferred as drug delivery carriers (lower melting point, lower crystalline and suitable for drug delivery); they are crystalline in nature and hydrophobic, rapidly release drugs, and are degraded by surface erosion [224]. PHA granule binding protein PhaP is able to bind to hydrophobic polymers [225]. A receptor-mediated drug-specific delivery system was developed in this study based on PhaP. The system consists of PHA nanoparticles, PhaP, and ligands fused to PhaP. The PHA nanoparticles were used to package mostly hydrophobic drugs. PhaP fused with ligands, produced by the overexpression of their corresponding genes in Pichia pastoris or E. coli, was able to attach to hydrophobic PHA nanoparticle. At the end, the ligands were able to pull the PhaP-PHA nanoparticles to the targeted cells with receptors recognized by the ligands. It was found in this study that the receptor-mediated drug-specific delivery system ligand-PhaP-PHA nanoparticles were taken up by macrophages, hepatocellular carcinoma cell BEL7402 in vitro, and hepatocellular carcinoma cells in vivo, respectively, when the ligands were mannosylated human a1-acid glycoprotein and human epidermal growth factor (hEGF), respectively, which were able to bind to receptors of macrophages or hepatocellular carcinoma cells. The system was clearly visible in the targeted cells and organs under fluorescence microscopy when rhodamine B isothiocyanate (RBITC) was used as a delivery model drug owing to the specific targeting effect created by specific ligand and receptor binding. The delivery system of hEGF-PhaP-nanoparticles carrying RBITC was found to be endocytosed by the tumor cells in a xenograft tumorous model mouse. Thus, the ligand-PhaP-PHA specific drug delivery system was proven effective both in vitro and in vivo [226]. 


\subsubsection{Biofuels}

Zhang et al. have first reported role of PHAs in biofuels as they have been esterified with poly- $R-3$ hydroxybutyrate (PHB) and medium chain length PHA (mcl PHA) via acid-catalyzed hydrolysis process to form $R$-3-hydroxybutyrate methyl ester (3HBME) and medium chain length hydroxyalkanoate methyl ester (3HAME) [158]. They investigated and recovered $97 \%$ and $96 \%$ percentage of 3HBME and 3HAME, respectively. Combustion heats of 3HAME, 3HBME, $n$-propanol, ethanol, 90\# gasoline, 0\# diesel, $n$-propanol, $n$-propanol, and 3HAME-based and 3HBME-based blended fuels were investigated and compared. The recovery percentages of 3HBME and $3 \mathrm{HAME}$ were $52 \%$ and $65 \%$, respectively. The purities of 3HBME and 3HAME were $97 \%$ and $96 \%$, respectively. The combustion value of 3HBME and 3HAME is 20 and $30 \mathrm{~kJ} \mathrm{~g}^{-1}$ and combustion value of ethanol is $27 \mathrm{~kJ} \mathrm{~g}^{-1}$ while we used additional $10-30 \%$ of 3HBME or 3HAME to chemical fuels that have enhanced the combustion value of 30 and $35 \mathrm{~kJ} \mathrm{~g}^{-1}$, respectively.

According to Wang et al. 3-hydroxybutyrate methyl ester (HBME) prepared by hydrolysis of poly-3-hydroxybutyrate (PHB) methanol acts as an esterification agent with the presence of sulphuric acid [84], while HBME was blended with 97\# gasoline in different ratios (5\%, 8.5\%, $10 \%, 15 \%$, and $20 \%)$ and it is found that there are similar fuel additive properties compared to ethanol in dynamic viscosity, oxygen content, boiling point, and flash point. The blended HBME and gasoline show only small difference compared to gasoline (distillation ranges and octane number (RON)). The PHAs application in the field of biofuels is an alternative and promising one as it does not require pure form of PHAs. However, the PHAs can also be obtained from nutrient waste water and activated sludge, and they do not compete with any human and/or animal food life cycles [227].

\subsection{CONCLUSION AND FUTURE PERSPECTIVES}

One of the major problems modern world is facing is the man-made pollution which intervenes in lot of natural process; hence to eliminate this undesired outcome researchers have focused on addressing this environmental problem. Though various remediation processes are available, the only feasible large scale remedy for this problem is bioremediation as it has numerous advantages over other modes of remediation. Marine bacteria which have the ability to survive extreme environmental conditions are the best option for potential utilization to remediate the toxic substances. Similarly they also have the ability to synthesize PHAs (biobased plastic) efficiently with the available nutrients and limiting factors. PHAs have all physical factors analogous to the conventional plastic but PHAs can be degraded easily. The only problem is the high production cost compared to the latter that could also be addressed by 
halophilic bacteria which synthesize PHAs in large quantity and thus fit for industrial scale production.

\section{REFERENCES}

1. $\quad$ S.K. Sen, S. Raut. J. Environ. Chem Eng. 3 (2015) 462-473.

2. A. Sivan. Curr. Opin. Biotechnol. 22 (2011) 422-426.

3. S. Khanna, A.K. Srivastava. Process Biochem. 40 (2005) 607-619.

4. W.Wanga, Z.Tanb, J. Penga, Q. Qiua, M. Lib. Mar. Environ. Res. 113 (2016) 7-17.

5. Plastics Europe. Plastics - the facts 2015. 1-30, http://www.plasticseurope.org/Document/plastics---the-facts-2015.aspx.

6. $\quad$ R.U. Halden. Annu. Rev. Public Health 31 (2010) 179-94.

7. P.C. Rem, S.Olsen, J.H. Welink, N. Fraunholcz. Environ. Eng. Manag. J. 8 (2009) 975-980.

8. R.C. Thompson, C.J. Moore, F.S. vom Saal, S.H. Swan. Philos. Trans. R. Soc. Lond. B. Biol. Sci. 364 (2009) 2153-2166.

9. E.J. Carpenter, S.J. Anderson, G.R. Harvey, H.P. Miklas, B.B. Peck. Science 178 (1972) 749-750.

10. A.A. Shah, F. Hasan, A. Hameed, S. Ahmed. Biotechnol. Adv. 26 (2009) 246-265.

11. T. Leejarkpai, U. Suwanmanee, Y. Rudeekit, T. Mungcharoen. Waste Manag. 31 (2011) 1153-1161.

12. G.Q. Chen. Plastics from Bacteria, Springer, Verlag Berlin Heidelberg, 2010, pp. 1-16.

13. J.R. Jambeck, R. Geyer, C. Wilcox, T.R. Siegler, M. Perryman, A. Andrady, R. Narayan, K.L. Law. Science 347 (2015) 768-771.

14. A.L. Lusher, G.H. Milian, J.O. Brien, S. Berrow, I.O. Connor, R. Officer. Environ. Pollut. 199 (2015) 185-191.

15. K.L. Law, R.C. Thompson. Science 345 (2014) 144-145.

16. M. Eriksen, L.C.M. Lebreton, H.S. Carson, M. Thiel, C.J. Moore, J.C. Borerro. Plos one 9 (2014) 1-15.

17. C.G. Avio, S. Gorbi, F. Regoli. Mar. Environ. Res. (In Press, Corrected Proof) 2016.

18. W.J. Sutherland, M. Clout, I.M. Cote, P. Daszak, M.H. Depledge, L. Fellman, E. Fleishman, R. Garthwaite, D.W. Gibbons, J.D. Lurio, A.J. Impey, F. Lickorish, D. Lindenmayer, J. Madgwick, C. Margerison, T. Maynard, L.S. Peck, J. Pretty, S. Prior, K.H. Redford, J.P.W. Scharlemann, M. Spalding, A.R. Watkinson. Trends Ecol. Evol. 25 (2010) 1-7.

19. C. Reed. New Sci. 225 (2015) 28-32.

20. A. Karen, H. Luke, T.Andrew. Marine Poll. Bull. 60 (2010) 2050-2055.

21. A. Bakir, S.J. Rowland, R.C. Thompson. Environ. Pollut. 185 (2014) 16-23.

22. L.M. Riosa, C. Moore, P.R. Jonesa. Mar. Pollut. Bull. 54 (2007) 1230-1237.

23. E.L. Teuten, J.M. Saquing, D.R.U. Knappe, M.A. Barlaz, S. Jonsson, A. Björn, S.J. Rowland, R.C. Thompson, T.S. Galloway, R .Yamashita, D. Ochi, Y. Watanuki, C. Moore, P.H. Viet, T.S. Tana, M. Prudente, R. Boonyatumanond, M.P. Zakaria, K. Akkhavong, Y. Ogata, H.Hirai, S. Iwasa, K. Mizukawa, Y.Hagino, A. Imamura, M. Saha, H. Takada. Philos. Trans. R. Soc. Lond. B 364 (2009) 2027-2045.

24. A. Turner, L.A. Holmes. Environ. Chem. 12 (2015) 600-610

25. R.E. Engler. Environ. Sci. Technol. 46 (2012) 12302-12315. 
26. D. Lobelle, M. Cunliffe. Marine Poll. Bull. 62 (2010) 197-200.

27. K.L. Law, S.M. Ferguson, N.A. Maximenko, G. Proskurowski, E.E. Peacock, J.Hafner, C.M. Reddy. Science 329 (2010) 1185-1188.

28. K.L. Law, S.E. Morét-Ferguson, D.S. Goodwin, E.R. Zettler, E. Deforce, T. Kukulka, G. Proskurowski. Environ. Sci. Technol. 48 (2014) 4732-4738.

29. S.C. Gall, R.C. Thompson. Marine Poll. Bull. 92 (2015) 170-179.

30. G.H. Balazs. Work. Fate Impact Mar. Debris Southwest Fisheries Center, U.S, 1985, p. 387-429.

31. B.F.S. Dias, T.E. Lovejoy. CBD Technical Series. Canada, 2012, p 1-61.

32. M.C. Goldstein, M. Rosenberg, L. Cheng. Biol. Lett. 8 (2012) 817-820.

33. H.S. Carson, S.L. Colbert, M.J. Kaylor, K.J McDermid. Marine Poll. Bull. 62 (2011) 1708-1713.

34. N.J. Mantua, S.R. Hare, Y. Zhang, J.M. Wallace, R.C.Francis. Meteorol. Soc. 78 (1997) 1069-1079.

35. B.H. Rehm. Biochem. J. 15 (2003) 15-33.

36. P.C. Rem, S. Olsen, J.H. Welink. N. Fraunholcz. Environ. Eng. Manag. J. 8 (2009) 975-980.

37. C. Stapp. Zentbl. Bakteriol. II 61(1924) 276-292.

38. M. Lemoigne. Bull. SocChimBiol 8 (1926) 770-782.

39. M. Lemoigne. Ann. Inst. Pasteur 41 (1927) 148-165.

40. D.H. Williamson, J.F. Wilkinson. J. Appl. Microbiol. 19 (1958) 198-209.

41. L.L. Wallen, W.K. Rohwedder. Environ. Sci. Technol. 8 (1974) 576-579.

42. R.H. Findlay, D.C. White. Appl. Environ. Microbiol. 45 (1983) 71-78.

43. M.J. De Smet, G. Eggink, B. Witholt, J. Kingma, H. Wynberg. J. Bacteriol. 154 (1983) 870-878.

44. Y. Doi. Microbial polyesters, New York, U.S, VCH Publishers, p.166.

45. M. Kunioka, Y. Nakamura, Y. Doi. Polymer Commun. 29 (1988) 174-176.

46. Y. Doi, A.Tamaki, M. Kunioka, K. Soga. Macromol. Rapid Commun. 8 (1987) 631-635.

47. A.J. Anderson, E.A. Dawes, Microbiol. Rev. 54 (1990) 450-472.

48. A. Steinbuechel. Biomaterials, Macmillan Publishers Ltd, New York, USA, 1991, p. $123-213$.

49. A. Steinbüchel. Macromol. Biosci. 1 (2001) 1-24.

50. M. Zinn, B. Witholt, T. Egli. Adv. Drug Deliv. Rev. 53 (2001) 5-21

51. O.P. Peoples, A.J. Sinskey. J. Biol. Chem. 264 (1989) 15298-15303.

52. P. Schubert, A. Steinbüchel, H.G. Schlegel. J. Bacteriol. 170 (1988) 5837-5847.

53. S.C. Slater, W.H. Voige, D.E. Dennis. J. Bacteriol. 170 (1988) 4431-4436.

54. C.S. Ha, W.J. Cho. Prog. Polym. Sci. 27 (2002) 759-809.

55. T. Keshavarz, I. Roy. Curr. Opin. Microbiol. 13 (2010) 321-326.

56. Y.U. Jian, H. Stahl. Bioresour. Technol. 99 (2008) 8042-8048.

57. R.M. Macrae, J.F. Wilkinson. J. Gen. Microbiol. 19 (1958) 210-222.

58. H.R. Dash, N. Mangwani, J. Chakraborty, S. Kumari, S. Das. Appl. Microbiol. Biotechnol. 97 (2013) 561-571.

59. A. Poli, G. Anzelmo, B. Nicolaus. Mar. Drugs 8 (2008) 1779-1802.

60. M. Hassanshahian. Marine Poll. Bull. 86 (2014) 361-366.

61. T.A. Gianoulis, J. Raes, P.V. Patel, R. Bjornson, J.O. Korbel, I. Letunic, T. Yamada, A. Paccanaro, L.J. Jensen, M. Snyder, P. Bork, M.B. Gerstein. Proc. Natl. Acad. Sci. USA 106 (2009) 1374-1379.

62. P. Baumann, L. Baumann, M. Mandel. J. Bacteriol. 107 (1971) 268-294. 
63. J.D. Oliver, R.R. Colwell. J. Bacteriol. 114 (1973) 897-908.

64. W.J. Page, A. Cornish. Appl. Environ. Microbiol. 59 (1993) 4236-4244.

65. W. Sun, J.G. Cao, K. Teng, E.A. Meighen. J. Biol. Chem. 269 (1994) 20785-20790.

66. J. Choi, S.Y. Lee, K. Han. Appl. Environ. Microbiol. 64 (1998) 4897-4903.

67. F. Wang, S.Y. Lee. Appl. Environ. Microbiol. 63 (1997) 3703-3706.

68. H.M. Alvarez, O.H. Pucci, A. Steinbüchel. Appl. Microbiol. Biotechnol. 47 (1997) 132-139.

69. F. Rodriguez-Valera, J.A.G. Lillo. FEMS Microbiol. Lett. 103 (1992) 181-186.

70. N. Taga, K. Tanaka, A. Ishizaki. Biotechnol. Bioeng. 53 (1997) 529-533.

71. T. Hai, D. Lange, R. Rabus, A. Steinbüchel. Appl. Environ. Microbiol. 70 (2004) 4440-4448.

72. T.M. Don, C.W. Chen, T.H. Chan. J. Biomater. Sci. Polym. Ed. 17 (2006) 1425-1438.

73. S. Cheng, G.Q. Chen, M. Leski, B. Zou, Y. Wang, Q. Wu. Biomaterials 27 (2006) 3758-3765.

74. T.Y. Huang, K.J. Duan, S.Y. Huang, C.W. Chen. J. Ind. Microbiol. Biotechnol. 33 (2006) 701-706.

75. C.-C. Chien, C.-C. Chen, M.-H. Choi, S.-S Kung, Y.-H. Wei. J. Biotechnol. 132 (2007) 259-263.

76. M. Koller, P. Hesse, R. Bona, C. Kutschera, A. Atlić, G. Braunegg. Macromolecular Symposia 253 (2007) 33-39.

77. Y. González-García, J. Nungaray, J. Córdova, O. González-Reynoso, M. Koller, A. Atlic, G. Braunegg. J. Ind. Microbiol. Biotechnol. 35 (2008) 629-633.

78. A. López-Cortés, A. Lanz-Landázuri, J.Q. García-Maldonado. Microb. Ecol. 56 (2008) 112-120.

79. C. Simon-Colin, K. Alain, S. Colin, J. Cozien, B. Costa, J.G. Guezennec, G.H. Raguénès. J. Appl. Microbiol. 104 (2008) 581-586.

80. J. Quillaguamán, T. Doan-Van, H. Guzmán, D. Guzmán, J. Martín, A. Everest, R. Hatti-Kaul. Appl. Microbiol. Biotechnol. 78 (2008) 227-232.

81. A. López-Cortés, A. Lanz-Landázuri, J.Q. García-Maldonado. Microb. Ecol. 56 (2008) 112-120.

82. A. Arun, R. Arthi, V. Shanmugabalaji, M. Eyini. Bioresour. Technol. 100 (2009) 2320-2323.

83. A. Shrivastav, S.K. Mishra, B. Shethia, I. Pancha, D. Jain, S. Mishra. Int. J. Biol. Macromol. 47 (2010) 283-287.

84. Q. Wang, H. Zhang, Q. Chen, X. Chen, Y. Zhang, Q. Qi. World J. Microbiol. Biotechnol. 26 (2010) 1149-1153.

85. S.R. Pandian, V. Deepak, K. Kalishwaralal, N. Rameshkumar, M. Jeyaraj, S. Gurunathan. Bioresour. Technol. 101 (2010) 705-711.

86. Y.H. Wei, W.C. Chen, H.S. Wu, O.M. Janarthanan. Mar. Drugs 9 (2011) 615-624.

87. K. Numata, Y. Doi. Mar. Biotechnol. 3 (2016) 323-331.

88. G. Sathiyanarayanan, G. Saibaba, G.S. Kiran, J. Selvin. Int. J. Biol. Macromol. 59 (2013) 170-177.

89. G. Sathiyanarayanan, G. S. Kiran, J. Selvin, G. Saibaba. Int. J. Biol. Macromol. 60 (2013) 253-261.

90. R.S. Sasidharan, S.G. Bhat, M. Chandrasekaran. Ann. Microbiol. 65 (2015) 455-465.

91. S.S. Sawant, B.K. Salunke, B.S. Kim. Curr. Microbiol. 69 (2014) 832-838.

92. M. Ramezani, M.A. Amoozegar, A. Ventosa. Ann. Microbiol. 65 (2015) 517-526. 
93. J.H. Dhangdhariya, S. Dubey, H.B. Trivedi, I. Pancha, J.K. Bhatt, B.P. Dave, S. Mishra. Int. J. Biol. Macromol. 76 (2015) 254-261.

94. P. Bhagowati, S. Pradhan, H.R. Dash, S. Das. Biosci. Biotechnol. Biochem. 79 (2015) 1454-1463.

95. C.-C. Sung, Y.Tachibana, K. Kasuya. Polym. Degrad. Stab. 129 (2016) 212-221.

96. G. Debashish, S. Malay, S. Barindra, M. Joydeep. Adv. Biochem. Eng. Biotechnol. 96 (2005) 189-218.

97. K. Gouffi, T. Bernard, C. Blanco. App. Environ. Microbiol. 66 (2000) 2358-2364.

98. S.-S.T. Hua, V.Y. Tsai, G.M. Lichens, A.T. Noma. App. Environ. Microbiol. 44 (1982) 135-140.

99. P. Aneja, T.C. Charles. J. Biotechnol. 18 (1999) 849-857.

100. A. Oren. Saline Systems 15 (2008) 1-13.

101. M.F. Roberts. Saline Systems 1 (2005) 1-30.

102. D. Desmarais, E.P. Jablonski, N.S. Fedarko, M.F. Roberts. Am. Soc. Microbiol. 179 (1997) 3146-3153.

103. R.G. Kirk, M. Ginzburg. J. Ultrastruct. Res. 41 (1972) 80-94.

104. J.G. Lillo, F. Rodriguez-Valera. Appl. Environ. Microbiol. 56 (1990) 2517-2521.

105. S.Y. Lee. Trends Microbiol. 14 (1996) 431-438.

106. H.F. Valentin D. Dennis. Appl. Environ. Microbiol. 62 (1996) 372-379.

107. A. Steinbüchel, B. Füchtenbusch. Trends Biotechnol. 16 (1998) 419-427.

108. R.V. Nonato, P.E. Mantelatto, C.E.V. Rossell. Appl. Microbiol. Biotechnol. 57 (2001) 1-5.

109. P.M. Halami. World J. Microbiol. Biotechnol. 24 (2008) 805-812.

110. R.D. Ashby, D.K.Y. Solaiman, T. Foglia. J. Ind. Microbiol. Biotechnol. 28 (2002) 147-153.

111. G. Du, J. Chen, J. Yu, S. Lun. J. Biotechnol. 88 (2001) 59-65.

112. R. Li, Q. Chen, P.G. Wang, Q. Qi. Appl. Microbiol. Biotechnol. 75 (2007) 1103-1109.

113. T.D. Full, D.O. Jung, M.T. Madigan. Lett. Appl. Microbiol. 43 (2006) 377-384.

114. D.K.Y. Solaiman, R.D. Ashby, A.T. Hotchkiss, T.A. Foglia. Biotechnol. Lett. 28 (2006) 157-162.

115. M.G.E. Albuquerque, M. Eiroa, C. Torres, B.R. Nunes, M.A. Reis. J. Biotechnol. 130 (2007) 411-421.

116. S. Bengtsson, A.R. Pisco, M.A.M. Reis, P.C. Lemos. J. Biotechnol. 145 (2010) 253-263.

117. S. Kulpreecha, A. Boonruangthavorn, B. Meksiriporn, N. Thongchul. J. Biosci. Bioeng. 107 (2009) 240-245.

118. J. Mozejko, S. Ciesielski. Biotechnol. Prog. 30 (2014) 1243-1246.

119. S. Obruca, I. Marova, O. Snajdar, L. Mravcova, Z. Svoboda. Biotechnol. Lett. 32 (2010) 1925-1932.

120. V. Kachrimanidou, N. Kopsahelis, A. Chatzifragkou, S. Papanikolaou, S. Yanniotis, I. Kookos, A.A. Koutinas. Waste Biomass Valorization 4(3) (2013) 529-537.

121. A. De Almeida, P.I. Nikel, A.M. Giordano, M.J. Pettinari. Appl. Environ. Microbiol. 73 (2007) 7912-7916.

122. D.K. Solaiman, R.D. Ashby, A.T. Hotchkiss, T.A. Foglia. Biotechnol. Lett. 28 (2006) 157-162.

123. D.K.Y. Solaiman, R.D. Ashby, T.A. Foglia. Appl. Microbiol. Biotechnol. 56 (2001) 664-669. 
124. T. Fukui, Y. Doi. Appl. Microbiol. Biotechnol. 49(1998) 333-336.

125. M. Yilmaz, Y. Beyatli. Zuckerindustrie 130 (2005) 109-112.

126. U. Rao, R. Sridhar, P.K.Sehgal. Biochem. Eng. J. 49 (2010) 13-20.

127. L.E.A. Munoz, M.R. Riley. Biotechnol. Bioeng. 100 (2008) 882-888.

128. L.F. Silva, M.K. Taciro, M.E. Michelin Ramos, J.M. Carter, J.G.C. Pradella, J.G.C. Gomez. J. Ind. Microbiol. Biotechnol. 31(6) (2004) 245-254.

129. J. Yu, H. Stahl. Bioresour. Technol. 99 (2008) 8042-8048.

130. E.J. Bormann, M. Roth. Biotechnol. Lett. 21 (1999) 1059-1063.

131. I.L. García, J.A. López, M.P. Dorado, N. Kopsahelisc, M. Alexandric, S. Papanikolaouc, M.A. Villarb, A.A. Koutinas. Bioresour. Technol. 130 (2013) 16-22.

132. E. Shimamura, K. Kasuya, G. Kobayashi, T. Shiotani, Y. Shima, Y. Doi. Macromolecules 27 (1994) 878-880.

133. Y. Jiang, X. Song, L. Gong, P. Li, C. Dai, W. Shao. Enzyme Microb. Technol. 42 (2008) 167-172.

134. J. Wang, J. Yu. Process Biochem. 36 (2000) 201-207.

135. P.I. Nikel, A. De Almeida, E.C. Melillo, M.A. Galvagno, M.J. Pettinari. Appl. Environ. Microbiol. 72 (2006) 3949-3954.

136. K. Sujatha, R. Shenbagarathai. Lett. Appl. Microbiol. 43 (2006) 607-614.

137. L.E.A. Munoz, M.R. Riley. Biotechnol. Bioeng. 100 (2008) 882-888.

138. A. Nath, M. Dixit, A. Bandiya, S. Chavda, A.J. Desai. Bioresour. Technol. 99 (2008) 5749-5755.

139. S. Povolo, P. Toffano, M. Basaglia, S. Casella. Bioresour. Technol. 101 (2010) 7902-7907.

140. A.A. Koutinas, Y. Xu, R. Wang, C. Webb. Enzyme Microb. Technol. 40 (2007) 1035-1044.

141. D. Van-Thuoc, J. Quillaguamán, G. Mamo, B. Mattiasson. J. Appl. Microbiol. 104 (2008) 420-428.

142. J.L. Bertrand, B.A. Ramsay, C. Chavarie. Appl. Environ. Microbiol. 56 (1990) 3133-3138.

143. W.-H. Lee, M.N.M. Azizan, K. Sudesh. Polym. Degrad. Stab. 84 (2004) 129-134.

144. M. Tohyama, S. Takagi, K. Shimizu. J. Biosci. Bioeng. 89 (2000) 323-328.

145. G. Eggink, H.van der Wal, G.N.M. Huijberts, P. de Waard. Ind. Crops Prod. 1 (1992) 157-163.

146. W.N. Chaudhry, N. Jamil, I. Ali, M.H. Ayaz, S. Hasnain. Ann. Microbiol. 61 (2011) 623-629.

147. J.H. Song, C.O. Jeon, M.H. Choi, S.C. Yoon, W. Park. J. Microbiol. Biotechnol. 18 (2008) 1408-1415.

148. A.A. Koutinas, I.L. Garcia, N. Kopsahelis, S.Papanikolaou, C. Webb, M.A. Villar, J.A. López. Waste Biomass Valorization 4 (2013) 359-370.

149. Z.T. Dobroth, S. Hu, E.R. Coats, A.G. McDonald. Bioresour. Technol. 102 (2011) 3352-3359.

150. S. Bengtsson, A.Werker, T. Welander. Water Sci. Technol. 58 (2008) 323-330.

151. T.Y. Wu, A.W. Mohammad, J.M. Jahim, N. Anuar. Biotechnol. Adv. 27 (2009) 40-52.

152. J. Yu. J. Biotechnol. 86 (2001) 105-112.

153. G. Pozo, A.C. Villamar, M. Martínez, G. Vidal. Water Sci. Technol. 63 (2011) 449-455. 
154. K.S. Ng, Y.M. Wong, T. Tsuge, K. Sudesh. Process Biochem. 46 (2011) 1572-1578.

155. I.S. Aldor, J.D. Keasling. Curr. Opin. Biotechnol. 14 (2003) 475-483.

156. I.K. Kang, S.H. Choi, D.S. Shin, S.C. Yoon. Int. J. Biol. Macromol. 28 (2001) 205-212.

157. A. Steinbüchel, H. Valentin, A. Schönebaum. J. Environ. 2 (1994) 67-74.

158. X. Zhang, R. Luo, Z. Wang, Y. Deng, G.Q. Chen. Biomacromolecules 10 (2009) 707-711.

159. B. Andreeßen, A.B. Lange, H. Robenek, A. Steinbüchel. Appl. Environ. Microbiol. 76 (2010) 622-626.

160. A. Steinbuchel, E.-M. Debzi, R.H. Marchessault, A. Timm. Appl. Microbiol. Biotechnol. 39 (1993) 443-449.

161. J. Jian, Z.J. Li, H.M. Ye, M.Q. Yuan, G.Q. Chen. Bioresour. Technol. 101 (2010) 6096-6102.

162. Q. Liu, G. Luo, X.R. Zhou, G.Q. Chen. Metab. Eng. 13 (2011) 11-17.

163. C.W. Chung, Y.S. Kim, Y.B. Kim, K.S. Bae, Y.H. Rhee. J. Microbiol. Biotechnol. 9 (1999) 847-853.

164. T.A. Leaf, M.S. Peterson, S.K. Stoup, D. Somers, F. Srienc. Microbiology 142 (1996) 1169-1180.

165. M. Yokouchi, Y. Chatani, H. Tadokoro, K. Teranishi, H. Tani. Polymer 14 (1973) 267-272.

166. H. Yamane, K. Terao, S. Hiki, Y. Kimura. Polymer 42 (2001) 3241-3248.

167. P.J. Barham, A. Keller, E.L. Otun, P.A. Holmes. J. Mater. Sci. 19 (1984) 2781-2794.

168. H. Mitomo, P.J. Barham, A. Keller. Polym. J. 19 (1987) 1241-1253.

169. D.G. Lundgren, R. Alper, C. Schnaitman, R.H. Marchessault. J. Bacteriol. 89 (1965) 245-251.

170. R. Marchessault, S. Coulombe, H. Morikawa, K. Okamura. Can. J. 59 (1981) 38-44.

171. S. Kusaka, T. Iwata, Y. Doi. J. Macromol. Sci. 35 (1998) 319-335.

172. Y. Doi, A. Segawa, M. Kunioka. Int. J. Biol. Macromol. 12 (1990) 106-111.

173. E. Rudnik. Compostable Polymer Materials, Elsevier, Amsterdam, Netherlands, 2008, p 199.

174. K. Sudesh, H. Abe, Y. Doi. Prog. Polym. Sci. 25 (2000) 1503-1555.

175. A.J. Anderson, E.A. Dawes. Microbiol. Rev. 54 (1990) 450-472.

176. M. Pötter, A. Steinbüchel. Biomacromolecules 6 (2005) 552-560.

177. R.M. Macrae, J.F. Wilkinson. J. Gen. Microbiol. 19 (1958) 210-222.

178. D. Kadouri, E. Jurkevitch, Y. Okon, S. Castro-Sowinski. Crit. Rev. Microbiol. 31 (2005) 55-67.

179. B.W. James, W.S. Mauchline, P.J. Dennis, C.W. Keevil, R. Wait. Appl. Environ. Microbiol. 65 (1999) 822-827.

180. N.I. López, J.A. Ruiz, B.S. Méndez. World J. Microbiol. Biotechnol. 14 (1998) 681-684.

181. Y. Okon, R. Itzigsohn. FEMS Microbiol. Rev. 103 (1992) 131-140.

182. J.A. Ruiz, N.I. Lopez, B.S. Mendez. Rev. Argent. Microbiol. 31 (1999) 201-204.

183. S. Tal, Y. Okon. Can. J. Microbiol. 31 (1985) 608-613.

184. W. Babel, J.U. Ackermann, U. Breuer. Adv. Biochem. Eng. Biotechnol. 71 (2001) 125-157.

185. S. Philip, T. Keshavarz, I. Roy. J. Chem. Technol. Biotechnol. 82 (2007) 233-247. 
186. S. Povolo, R. Tombolini, A. Morea, A.J. Anderson, S. Casella, M.P. Nuti. Can. J. Microbiol. 40 (1994) 823-829.

187. M.M. Rothermich, R. Guerrero, R.W. Lenz, S. Goodwin. Appl. Environ. Microbiol. 66 (2000) 4279-4291.

188. N.K. Arora, V. Singhal, D.K. Maheshwari. World J. Microbiol. Biotechnol. 22 (2006) 603-606.

189. Y. Asada, M. Miyake, J. Miyake, R. Kurane, Y. Tokiwa. Int. J. Biol. Macromolec. 25 (1999) 37-42

190. N.D. Ayub, M.J. Pettinari, J.A. Ruiz, N.I. López. Curr. Microbiol. 49 (2004) 170-174.

191. D. Kadouri, E. Jurkevitch, Y. Okon. Arch. Microbiol. 180 (2003) 309-318.

192. D. Kadouri, E. Jurkevitch, Y. Okon. Appl. Environ. Microbiol. 69 (2003) 3244-3250.

193. L.J. Raiger-Iustman, J.A. Ruiz. FEMS Microbiol. Lett. 284 (2008) 218-224.

194. K. Trautwein, S. Kühner, L. Wöhlbrand, T. Halder, K. Kuchta, A. Steinbüchel, R. Rabus. Appl. Environ. Microbiol. 74 (2008) 2267-2274.

195. L. Villanueva, A. Navarrete, J. Urmeneta, R. Geyer, D.C. White, R. Guerrero. Microb. Ecol. 54 (2007) 523-531.

196. Y.H. Zhao, H.M. Li, L.F. Qin, H.H. Wang, G.Q. Chen. FEMS Microbiol. Lett. 276 (2007) 34-41.

197. P. Aneja, M. Dai, D.A. Lacorre, B. Pillon, T.C. Charles. FEMS Microbiol. Lett. 239 (2004) 277-283.

198. S. Encarnación, M. Del Carmen Vargas, M.F. Dunn, A. Dávalos, G. Mendoza, Y. Mora, J. Mora. J. Bacteriol. 184 (2002) 2287-2295.

199. C. Wang, X. Sheng, R.C. Equi, M.A. Trainer, T.C. Charles, B.W.S. Sobral. J. Bacteriol. 189 (2007) 9050-9056.

200. M.A. Cevallos, S. Encarnación, A. Leija, Y. Mora, J. Mora. J. Bacteriol. 178 (1996) 1646-1654.

201. M.A. Trainer, T.C. Charles. Appl. Microbiol. Biotechnol. 71 (2006) 377-386.

202. V. Vassileva, G. Ignatov. Physiol. Plant. 114 (2002) 27-32.

203. D. Segura, T. Cruz, G. Espín. Arch. Microbiol. 179 (2003) 437-443.

204. S. Castro-Sowinski, S. Burdman, O. Matan, Y. Okon. Natural Functions of Bacterial Polyhydroxyalkanoates, in: Plastics from Bacteria, Springer,

Heidelberg Dordrecht London New York, 2010, p. 39-6.

205. Y. Doi, Y. Kanesawa, N. Tanahashi, Y. Kumagai. Polym. Degrad. Stab. 36 (1992) 173-177.

206. J. Mergaert, A. Webb, C. Anderson, A. Wouters, J. Swings. Appl. Environ. Microbiol. 59 (1993) 3233-3238.

207. M. Scandola, M.L. Focarete, G. Adamus, W. Sikorska, I. Baranowska, S. Świerczek, M. Gnatowski, M. Kowalczuk, Z. Jedliński. Macromolecules 30 (1997) 2568-2574.

208. D. Jendrossek, I. Knoke, R.B. Habibian, A. Steinbüchel, H.G. Schlegel. J. Environ. Polym. Degrad. 1(1993) 53-63.

209. K. Mukai, K. Yamada, Y. Doi. Polym. Degrad. Stab. 41 (1993) 85-91.

210. Y. Shirakura,T. Fukui, T. Saito, Y. Okamoto, T. Narikawa, K. Koide, K. Tomita, T. Takemasa, S. Masamune. Gen. Subj. 880 (1986) 46-53.

211. T. Tanio, T. Fukui, Y. Shirakura, T. Saito, K. Tomita, T. Kaiho, S. Masamune. Eur. J. Biochem. 124 (1982) 71-77.

212. K. Yamada, K. Mukai, Y. Doi. Int. J. Biol. Macromol. 15 (1993) 215-220. 
213. K.I. Kasuya, Y. Inoue, Y. Doi. Int. J. Biol. Macromol. 19 (1996) 35-40.

214. D. Dos Santos Rosa, M.R. Calil, C. Fassina Guedes, G. Das, T.C. Rodrigues. J. Polym. Environ. 12 (2004) 239-245.

215. S. Chanprateep. J. Biosci. Bioeng. 110 (2010) 621-632.

216. L. Shen, J. Haufe, M.K. Patel. Gr. Sci. Technol. Soc. 41 (2009) 243.

217. C.S. Reddy, R.Ghai, V. Rashmi, V.C. Kalia. Bioresourc. Technol. 87 (2003) 137-146.

218. G.Q. Chen, G. Zhang, S.J. Park, S.Y. Lee. Appl. Microbiol. Biotechnol. 57 (2001) 50-55.

219. Y. Wang, Y.-Z. Bian, Q. Wu, G.-Q. Chen. Biomaterials 29 (2008) 2858-2868.

220. Y.Z. Bian, Y. Wang, G. Aibaidoula, G.Q. Chen, Q. Wu. Biomaterials 30 (2009) 217-225.

221. G.Q. Chen, Q. Wu. Biomaterials 33 (2005) 6565-6578.

222. C. Loo, K. Sudesh. Malaysian Polym. J. 2 (2007) 31-57.

223. C.W. Pouton, S. Akhtar. Adv. Drug Deliv. Rev. 18 (1996) 133-162.

224. A. Mokhtarzadeh, A. Alibakhshi, M. Hejazi, Y. Omidi, J. Ezzati Nazhad Dolatabadi. Trends Anal. Chem. 82 (2016) 367-384.

225. Z. Wang, H. Wu, J. Chen, J. Zhang, Y. Yao, G.-Q. Chen. Lab Chip 11 (2008) 1957-1962.

226. Y.C. Yao, X.Y. Zhan, X.H. Zou, Z.H. Wang, Y.C. Xiong, J. Zhang, J. Chen, G.Q. Chen. Biomaterials 29 (2008) 4823-4830.

227. X. Gao, J.C. Chen, Q. Wu, G.Q.Chen. Curr. Opin. Biotechnol. 6 (2011) 768-774. 
Chapter 2 